\title{
FXYD2 and Na,K-ATPase Expression in Isolated Human Proximal Tubular Cells: Disturbed Upregulation on Renal Hypomagnesemia?
}

\author{
Edinio R. Cairo • Herman G. P. Swarts • Martijn J. G. Wilmer • \\ Peter H. G. M. Willems • Elena N. Levtchenko • \\ Jan Joep H. H. M. De Pont • Jan B. Koenderink
}

Received: 17 June 2009/Accepted: 8 October 2009/Published online: 29 October 2009

(c) The Author(s) 2009. This article is published with open access at Springerlink.com

\begin{abstract}
Autosomal dominant renal hypomagnesemia (OMIM 154020), associated with hypocalciuria, has been linked to a $121 \mathrm{G}$ to A mutation in the FXYD2 gene. To gain insight into the molecular mechanisms linking this mutation to the clinical phenotype, we studied isolated proximal tubular cells from urine of a patient and a healthy subject. Cells were immortalized and used to assess the effects of hypertonicity-induced overexpression of FXYD2 on amount, activity and apparent affinities for $\mathrm{Na}^{+}, \mathrm{K}^{+}$and ATP of Na,K-ATPase. Both cell lines expressed mRNA for FXYD2a and FXYD2b, and patient cells contained both the wild-type and mutated codons. FXYD2 protein expression was lower in patient cells and could be increased in both cell lines upon culturing in hyperosmotic medium but to a lesser extent in patient cells. Similarly,
\end{abstract}

\section{J. J. H. H. M. De Pont is deceased.}

E. R. Cairo - H. G. P. Swarts · P. H. G. M. Willems ·

J. J. H. H. M. De Pont

Department of Biochemistry, Radboud University Nijmegen

Medical Center, P.O. Box 9101, 6500 HB Nijmegen, The

Netherlands

\section{J. G. Wilmer}

Department of Pediatrics, Radboud University Nijmegen Medical Center, P.O. Box 9101, 6500 HB Nijmegen, The Netherlands

\section{E. N. Levtchenko}

Department of Pediatrics/Pediatric Nephrology, University

Hospital Gasthuisberg, Leuven, Belgium

J. B. Koenderink $(\square)$

Department of Pharmacology and Toxicology, Nijmegen Center for Molecular Life Sciences, Radboud University Nijmegen Medical Center, P.O. Box 9101, 6500 HB Nijmegen, The Netherlands

e-mail: j.koenderink@ncmls.ru.nl hyperosmotic culturing increased $\mathrm{Na}, \mathrm{K}$-ATPase protein expression and ATP hydrolyzing activity but, again, to a lesser extent in patient cells. Apparent affinities of $\mathrm{Na}, \mathrm{K}$ ATPase for $\mathrm{Na}^{+}, \mathrm{K}^{+}$and ATP did not differ between patient and control cells or after hyperosmotic induction. We conclude that human proximal tubular cells respond to a hyperosmotic challenge with an increase in FXYD2 and $\mathrm{Na}$,K-ATPase protein expression, though to a smaller absolute extent in patient cells.

Keywords Proximal tubular cells - Hypomagnesemia . FXYD2 - Na,K-ATPase

\section{Introduction}

Autosomal dominant renal hypomagnesemia (OMIM 154020 ), associated with hypocalciuria, is a disorder which has been linked to a $121 \mathrm{G}$ to A mutation in the FXYD2 gene (Meij et al. 2000). This mutation leads to a G41R substitution in the transmembrane domain of the FXYD2 protein (Na,K-ATPase $\gamma$-subunit). FXYD2 belongs to a family of seven mammalian members, all of which share the FXYD motif in the N-terminal domain. All family members have been shown to be able to associate with $\mathrm{Na}, \mathrm{K}-\mathrm{ATPase}$ and to alter its intrinsic properties (Crambert et al. 2002, 2005; Lubarski et al. 2005; Delprat et al. 2007; Beguin et al. 1997, 2001, 2002; Li et al. 2005; Arystarkhova et al. 1999; Therien et al. 1999). This together with their tissue-specific expression pattern has led to the hypothesis that they function as cell- and tissue-specific regulators of $\mathrm{Na}, \mathrm{K}$-ATPase.

Association of FXYD2 with Na,K-ATPase alters the apparent affinity for $\mathrm{K}^{+}$in a membrane potential-dependent manner (Arystarkhova et al. 1999; Beguin et al. 1997) 
and reduces $\mathrm{Na}^{+}$affinity (Arystarkhova et al. 1999; Beguin et al. 2001). The apparent affinity for ATP is also altered (Therien et al. 1999). The G41R substitution in the transmembrane domain of FXYD2, which is linked to hypomagnesemia, has been demonstrated to disrupt the association between Na,K-ATPase and FXYD2 (Meij et al. 2003; Pu et al. 2002). The molecular mechanism by which this lack of association leads to hypomagnesemia is not yet resolved. Thus far, studies of these molecular mechanisms have been hampered by the absence of a suitable human renal cell model. This limitation can, in principle, be overcome by the possibility of culturing renal cells derived from urine (Laube et al. 2005; Racusen et al. 1995).

In the present study, we cultured and characterized proximal tubular epithelial cells (PTECs) immortalized with human papillomavirus E6/E7 genes (HPV16 E6/E7) from the urine of a hypomagnesemia patient and compared their properties with those of cells derived from the urine of a healthy control. To this end, we determined the expression levels of FXYD2 and the Na,K-ATPase $\alpha$-subunit, the maximum ATPase activity and the apparent $\mathrm{Na}^{+}, \mathrm{K}^{+}$and ATP affinities of Na,K-ATPase under normo- and hyperosmotic culturing conditions. We show that the Na,KATPase $\alpha$-subunit and FXYD2 can be upregulated by exposing the cells to hyperosmolality, yet the absolute expression levels remain lower in patient cells compared to control cells. The increase in Na,K-ATPase expression is proportionate to an increase in maximal $\mathrm{Na}, \mathrm{K}$-ATPase activity, whereas it is not accompanied by changes in the apparent affinities for $\mathrm{Na}^{+}, \mathrm{K}^{+}$or ATP of the enzyme.

\section{Materials and Methods}

\section{PTE Cell Line Generation}

Urine was collected from a patient (35 years old, male) in whom the G41R mutation was confirmed previously (Meij et al. 2000) and used to obtain proximal tubular cells. Urine of a healthy subject (12 years old, male) was used for obtaining control proximal tubular cells. Proximal tubular cells were isolated as described previously (Wilmer et al. 2005). Urine was centrifuged $(223 \times g, 5 \mathrm{~min}$, room temperature) within $5 \mathrm{~h}$ after collection. After washing in phosphate-buffered saline (PBS) and a second centrifugation step, urine sediment was resuspended in $3 \mathrm{ml}$ PTEC culture medium (DMEM-Ham's F12; Cambrex Biosciences, East Rutherford, NJ) supplemented with $10 \%$ fetal calf serum (FCS), $100 \mathrm{U} / \mathrm{ml}$ penicillin (GIBCO, Grand Island, NY), $100 \mathrm{U} / \mathrm{ml}$ streptomycin (GIBCO), ITS (Sigma, St. Louis, MO; $5 \mu \mathrm{g} / \mathrm{ml}$ insulin, $5 \mu \mathrm{g} / \mathrm{ml}$ transferrin and $5 \mathrm{ng} / \mathrm{ml}$ selenium), $36 \mathrm{ng} / \mathrm{ml}$ hydrocortisone (Sigma), $10 \mathrm{ng} / \mathrm{ml}$ epidermal growth factor (EGF, Sigma) and $40 \mathrm{pg} / \mathrm{ml}$ triiodothyronine (Detrisac et al. 1984). The suspension was transferred to a $25-\mathrm{cm}^{2}$ tissue culture flask and placed at $37^{\circ} \mathrm{C}$ in a $5 \% \mathrm{CO}_{2}$ incubator. The medium was refreshed every 2 3 days. To maintain proliferation, cells at passage 4 or less were transfected with plasmid DNA, containing the HPV16 E6/E7 genes, using the amphotropic packaging cell line PA 317 (Ryan et al. 1994). The proximal tubular origin of cultured cells was confirmed by visual morphology and by flowcytometric analysis using CD13 (aminopeptidase N) antibodies, specific for PTECs.

\section{Cell Culture}

Cells were cultured at $37^{\circ} \mathrm{C}$ in a humidified $5 \% \mathrm{CO}_{2} / 95 \%$ air atmosphere in PTEC culture medium (osmolality 286$356 \mathrm{mosmol} / \mathrm{kg} \mathrm{H}_{2} \mathrm{O}$ ), supplemented with $50 \mathrm{mg} / \mathrm{ml}$ gentamycin (GIBCO). For hyperosmotic induction of FXYD2, cells were grown to $100 \%$ confluence, after which they were grown for another 2 days in medium supplemented as indicated in "Results." Care was taken not to cause changes in the $\mathrm{pH}$ of the culture medium. Patient and control cells were analyzed under the same conditions, to exclude experimental artifacts.

\section{RNA Isolation and cDNA Synthesis}

Cells were harvested by trypsinization, washed in PBS $\left(500 \times g, 1 \mathrm{~min}, 4^{\circ} \mathrm{C}\right)$ and resuspended in $500 \mu \mathrm{l}$ TRIzol (Invitrogen, Carlsbad, CA). After addition of $50 \mu \mathrm{l}$ chloroform and $0.2 \mathrm{mg} / \mathrm{ml}$ glycogen, the suspension was vortexed for $10 \mathrm{~s}$, incubated for $10 \mathrm{~min}$ at $4^{\circ} \mathrm{C}$, vortexed again and centrifuged $\left(12,000 \times g, 10 \mathrm{~min}, 4^{\circ} \mathrm{C}\right)$. Clear supernatant $(200 \mu \mathrm{l})$ was transferred to a small tube and $200 \mu \mathrm{l}$ of propanol-2 was added. The suspension was vortexed for $10 \mathrm{~s}$, incubated for $10 \mathrm{~min}$ at $4^{\circ} \mathrm{C}$, vortexed again and centrifuged $\left(16,000 \times g, 30 \mathrm{~min}, 4^{\circ} \mathrm{C}\right)$. The RNA pellet was washed in $70 \% \mathrm{EtOH}$, air-dried and taken up in $40 \mu \mathrm{l}$ of DEPC water. cDNA was synthesized using $300 \mathrm{ng}$ of isolated RNA as template and random primers.

\section{FXYD2 cDNA Detection}

FXYD2 cDNA was amplified for detection using specific primers for human FXYD2a (atgactgggttgtcgatggacggt), human FXYD2b (atggacaggtggtacctg) and the redundant reverse primer for human FXYD2 (ttacggctcatcttcattgatttg). PCR products were analyzed by agarose gel electrophoresis and sequencing.

Crude Membrane Preparation

Cells were harvested by trypsinization, washed in PBS $\left(500 \times \mathrm{g}, 1 \mathrm{~min}, 4^{\circ} \mathrm{C}\right)$ and resuspended in $500 \mu \mathrm{l} \mathrm{H}_{2} \mathrm{O}$ 
containing protease inhibitor (1 tablet/10 ml, per the manufacturer's protocol; Roche, Indianapolis, IN). After repeated freezing and thawing to lyse the cells, DNA was broken down by incubation with $100 \mathrm{U} / \mathrm{ml}$ Turbo DNase (10 min, $4^{\circ} \mathrm{C}$; Ambion, Austin, TX), after which the membranes were isolated by centrifugation $(16,000 \times g$, $30 \mathrm{~min}, 4^{\circ} \mathrm{C}$ ). The pellet was resuspended in $50 \mu \mathrm{lPBS}$ and stored at $-20^{\circ} \mathrm{C}$.

\section{Membrane Preparation}

Cells were harvested by incubation in PBS/10 mм EDTA at $37^{\circ} \mathrm{C}$ for $1 \mathrm{~h}$, after which they were scraped from the culture flasks and collected. After centrifugation $(2,000 \times g$, $5 \mathrm{~min}$ ), the cell pellet was resuspended in $5 \mathrm{ml} \mathrm{PBS} / 10 \mathrm{~mm}$ EDTA ( $\mathrm{pH}$ 7.0) containing protease inhibitor (per the manufacturer's recommendations). Cells were lysed by repeated freezing and thawing and homogenized by pulling through a needle. The homogenate was centrifuged $(200 \times g, 5 \mathrm{~min})$, after which the membranes were isolated from the supernatant by centrifugation $(100,000 \times g$, $60 \mathrm{~min}$ ). The pellet was resuspended in $500 \mu \mathrm{l} \mathrm{H}_{2} \mathrm{O}$, lyophilized, taken up in $400 \mu \mathrm{l}$ buffer $(250 \mathrm{~mm}$ sucrose, $50 \mathrm{~mm}$ Tris- $\mathrm{HCl}$ [pH 7.0] and 2 mм EDTA) and stored at $-20^{\circ} \mathrm{C}$.

\section{Protein Determination}

Protein concentrations were quantified with the modified Lowry method according to Peterson (1983) using bovine serum albumin as a standard.

\section{Western Blotting}

Membrane fractions were solubilized in sample buffer and analyzed on SDS-PAGE gels containing 15\% acrylamide according to Laemmli (1970). For immunoblotting, the separated proteins were transferred to Immobilon-P membranes (Millipore, Bedford, MA). FXYD2 subunits were detected with an antibody against the C-terminal end (Or et al. 1996), kindly provided by Dr. S. Karlish (Rehovot, Israel), whereas the $\alpha$-subunit of $\mathrm{Na}, \mathrm{K}$-ATPase was detected with antibody C356-M09 (Koenderink et al. 2003). Primary antibodies were detected using an antirabbit secondary antibody, labeled with horseradish peroxidase (Dako, Copenhagen, Denmark).

\section{ATPase Activity Assay}

ATPase activity was determined using a radiochemical method. For this purpose, $0.1 \mathrm{mg}$ of membranes was added to $100 \mu \mathrm{l}$ of medium containing (in $\mathrm{mm}$ ) $0.8 \mathrm{MgCl}_{2}, 0.1$ EGTA, 0.2 EDTA, 1 TrisN $_{3}$ and 50 Tris- $\mathrm{HCl}$ (pH 7.0), as well as various concentrations of activating cations and $\mathrm{Mg}-\left[\gamma_{-}{ }^{32} \mathrm{P}\right]-\mathrm{ATP}$ as indicated in "Results." Ionic strength was kept constant with choline chloride. After incubation for $30 \mathrm{~min}$ at $37^{\circ} \mathrm{C}$, the reaction was stopped by adding $500 \mu 110 \%(\mathrm{w} / \mathrm{v})$ charcoal in 6\% (v/v) trichloroacetic acid, and after $10 \mathrm{~min}$ at $0^{\circ} \mathrm{C}$, the mixture was centrifuged for $10 \mathrm{~s}$ at $10,000 \times g$. To $0.15 \mathrm{ml}$ of clear supernatant, containing the liberated inorganic phosphate $\left({ }^{32} \mathrm{P}_{\mathrm{i}}\right), 3 \mathrm{ml}$ OptiFluor (Canberra Packard, Tilburg, The Netherlands) was added, and the mixture was analyzed by liquid scintillation analysis. In general, blanks were prepared by incubating in the absence of membranes. Na,K-ATPase activity is presented as the difference in activity between total ATPase (cations as indicated) and $\mathrm{Mg}^{2+}$-ATPase (no $\mathrm{Na}^{+}$and $\mathrm{K}^{+}$ present, with $10 \mathrm{~mm}$ ouabain present).

\section{Analysis of Data}

Differences were tested for significance by means of Student's $t$-test. $K_{0.5}$ values were determined by analyzing the plots using the nonlinear curve-fitting program (Hill equation function) of Origin 6.1 (OriginLab, Northhampton, MA).

\section{Results}

\section{PTE Cell Line Generation}

After culturing of urine sediments, colonies with cobblestone morphology appeared in urine samples of both healthy control and hypomagnesemia subjects. Cultured cells were immortalized by transfection with HPV E6/E7 genes. Although PETC markers were positive (see "Materials and Methods"), we cannot with absolute certainty exclude mixed cell populations.

\section{cDNA Characterization}

RNA was isolated from patient and control cell lines, both of which were induced by an increase in osmolality of $200 \mathrm{mosmol} / \mathrm{kg} \mathrm{H}_{2} \mathrm{O}$ using sucrose. cDNA was synthesized and subsequently analyzed by performing PCRs with primers designed to pick up human FXYD2a and FXYD2b. Analysis of the PCR products on agarose gel indicated the presence of both FXYD2a and FXYD2b cDNA, which was confirmed by sequencing (data not shown). Sequencing furthermore revealed that the control cell line had only a guanine at position 121, whereas the patient cell line had both a wild-type guanine signal and a mutant adenine signal in both FXYD2a (Fig. 1) and FXYD2b (data not shown). The latter indicates that patient cells are heterozygous and that both alleles are transcribed. 
A
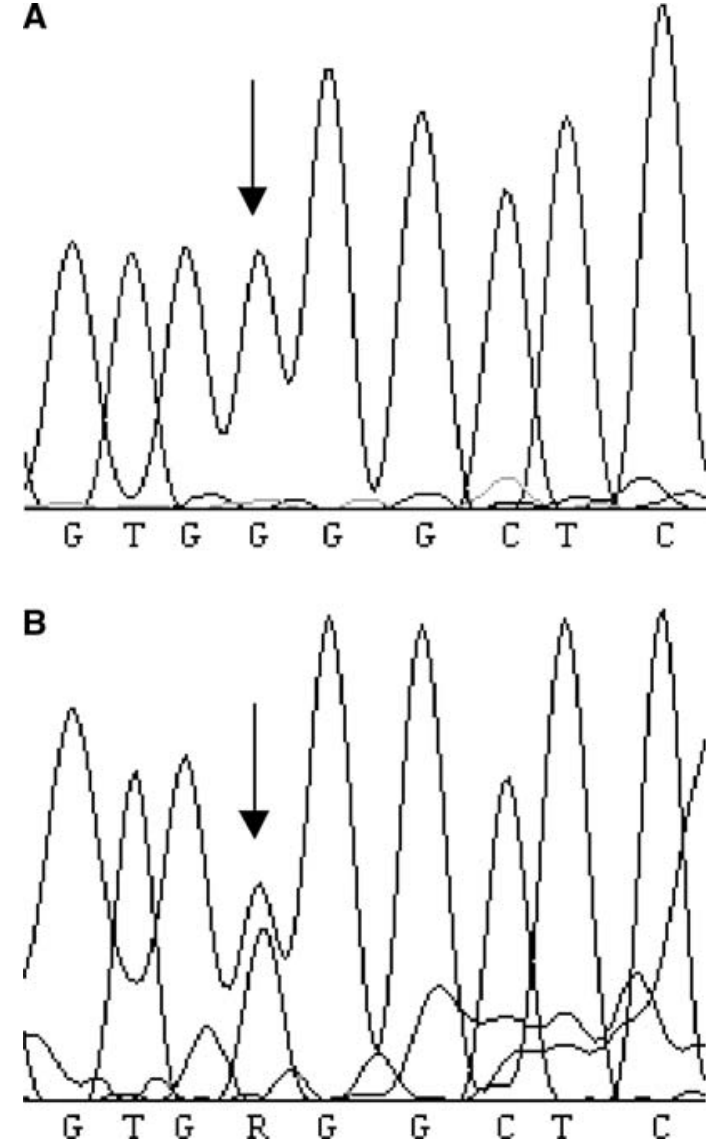

Fig. 1 Partial sequence of FXYD2. RNA isolation and cDNA synthesis were performed as described in "Materials and Methods." a Control products showing a wild-type guanine signal (arrow) in the FXYD2a cDNA sequence. b Patient products showing a heterozygous guanine and adenine signal ( $\mathrm{R}$, arrow) in the FXYD2a cDNA sequence

\section{Hyperosmotic Challenges}

The crude membrane isolations of the cell lines were analyzed on SDS-PAGE, to visualize the presence of FXYD2 and the catalytic subunit $(\alpha)$ of Na,K-ATPase. After several passages at normal osmolality, the amount of FXYD2 in the membrane fractions diminished (data not shown), in line with literature data (Capasso et al. 2001; Wetzel et al. 2004) showing that various cell lines originating from the kidney do not express FXYD2 unless they are exposed to hyperosmotic medium. Indeed, exposure of our cell lines to hyperosmotic medium (raised by 200 mosmol $/ \mathrm{kg} \mathrm{H}_{2} \mathrm{O}$ with $\mathrm{NaCl}$ ) raised the amount of FXYD2 observed on Western blot, with little or no effect on the amount of expressed $\alpha$-subunit (Fig. 2, lanes 1 and 2). Exposure of the cells to an additional $200 \mathrm{mosmol} / \mathrm{kg}$ $\mathrm{H}_{2} \mathrm{O}$ choline chloride (Fig. 2, lane 4) gave similar results as $200 \mathrm{mosmol} / \mathrm{kg} \mathrm{H}_{2} \mathrm{O} \mathrm{NaCl}$. Exposure to an additional 200 mosmol/kg $\mathrm{H}_{2} \mathrm{O}$ sucrose (Fig. 2, lane 5) showed an even larger increase in FXYD2 expression. In contrast, exposure to neither an additional $200 \mathrm{mosmol} / \mathrm{kg} \mathrm{H}_{2} \mathrm{O}$ sodium acetate (Fig. 2, lane 3) nor $200 \mathrm{mosmol} / \mathrm{kg} \mathrm{H}_{2} \mathrm{O}$ urea (Fig. 2, lane 6) increased FXYD2 expression. In addition, expression of FXYD2 seemed to be lower in patient cells under all conditions compared to control cells.

\section{Na,K-ATPase Expression and Activity}

The presence of the $\alpha$-subunit and FXYD2 in samples used for ATPase activity measurements was visualized on Western blot (Fig. 3). When cultured in hypertonic medium (additional $200 \mathrm{mosmol} / \mathrm{kg} \mathrm{H}_{2} \mathrm{O}$ sucrose), the relative intensity of $\alpha$-subunit and FXYD2 staining increased $1.7 \pm 0.2$-fold and $5 \pm 1.0$-fold for control cells and $1.3 \pm 0.5$-fold and $6.1 \pm 2.3$-fold for patient cells, respectively. The expression level of FXYD2 in patient cells was only $35 \pm 10 \%$ of that in control cells (normosmotic conditions). Also, the expression levels of the $\mathrm{Na}, \mathrm{K}$-ATPase $\alpha$-subunit seemed to be higher in the control cell line.

In the presence of ATP, $\mathrm{Na}^{+}$and $\mathrm{K}^{+}$, the total $\mathrm{Na}, \mathrm{K}$ ATPase activity measured in isolated membranes increased for both patient and control cells (Fig. 4a), though the increase was less in the patient cells. Control fractions showed a maximum activity of $2.86 \pm 0.11 \mu \mathrm{mol} \mathrm{Pi} \mathrm{mg}{ }^{-1}$ protein $\mathrm{h}^{-1}$ from noninduced cultures and $4.89 \pm 0.07 \mu \mathrm{mol}$ $\mathrm{Pi} \mathrm{mg}{ }^{-1}$ protein $\mathrm{h}^{-1}$ from induced cultures. The membrane

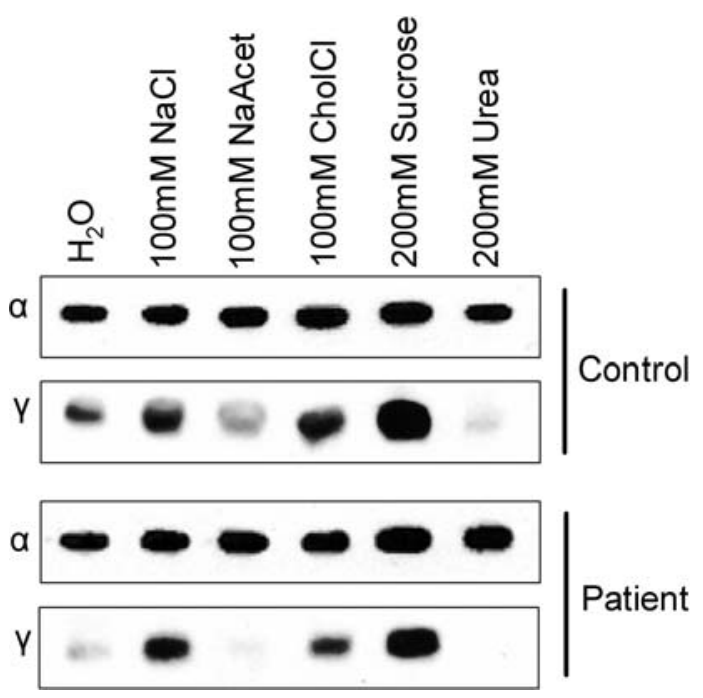

Fig. 2 Expression of Na,K-ATPase $\alpha$-subunit and FXYD2 in crude membrane isolations of control and patient cell lines. Crude membrane isolation and Western blot were performed as described in "Materials and Methods." Top labels show the rise in osmolality compared to normal medium. Expression of FXYD2 is clearly influenced by increasing the osmolality with the aid of $\mathrm{NaCl}$, choline chloride and sucrose compared to control samples. No or very minor effects are seen with sodium acetate or urea. Shown is a representative of two experiments 


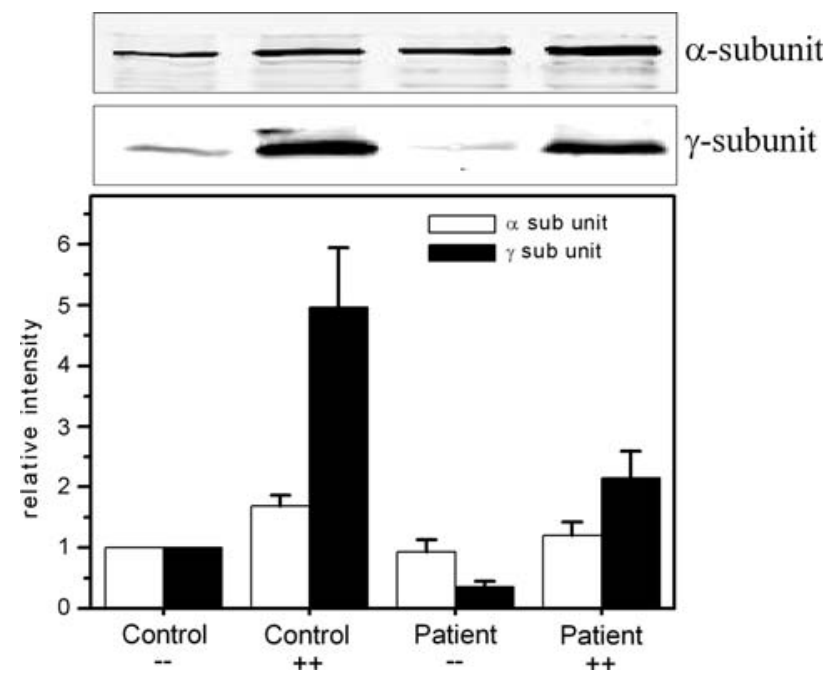

Fig. 3 Expression of Na,K-ATPase $\alpha$-subunit and FXYD2 in isolated membranes of control and patient cell lines. Membrane isolation and Western blot were performed as described in "Materials and Methods." Equal amounts of protein were loaded per well. When induced with an additional $200 \mathrm{mosmol} / \mathrm{kg} \mathrm{H}_{2} \mathrm{O}$ of sucrose, indicated by ++ , expression of both subunits is enhanced. Shown are means \pm SE of three enzyme preparations

fractions from patient material showed a maximum activity of $2.37 \pm 0.24 \mu \mathrm{mol} \mathrm{Pi} \mathrm{mg}{ }^{-1}$ protein $\mathrm{h}^{-1}$ from noninduced cultures and $3.02 \pm 0.18 \mu \mathrm{mol} \mathrm{Pi} \mathrm{mg}{ }^{-1}$ protein $\mathrm{h}^{-1}$ from induced cultures. $\mathrm{Mg}^{2+}$-ATPase activity, measured in the absence of $\mathrm{Na}^{+}$and $\mathrm{K}^{+}$and in the presence of ouabain, was virtually the same for control and patient material and did not alter upon induction. When corrected for the relative intensity of isolated $\alpha$-subunit on Western blot (Fig. 3), the samples showed no significant differences in activity (Fig. 4b). This finding indicates that the increase in ATPase activity can be fully explained by the sucrose-induced increase in $\mathrm{Na}, \mathrm{K}$-ATPase $\alpha$-subunit expression.

In membrane samples from noninduced control cultures, the apparent affinities for ATP (Fig. 5), $\mathrm{Na}^{+}$(Fig. 6) and
$\mathrm{K}^{+}$(Fig. 7) were $0.54 \pm 0.05,9.1 \pm 0.8$ and $1.38 \pm$ $0.26 \mathrm{~mm}$, respectively (Table 1 ). Essentially the same values were found after induction with sucrose $(0.51 \pm$ $0.04,8.7 \pm 0.6$ and $1.24 \pm 0.1 \mathrm{~mm}$, respectively). Corresponding values obtained with samples from noninduced $(0.68 \pm 0.07,8.8 \pm 0.7$ and $1.79 \pm 0.18 \mathrm{~mm}$, respectively $)$ and induced $(0.59 \pm 0.05, \quad 8.3 \pm 0.9$ and $1.61 \pm 0.11 \mathrm{~mm}$, respectively) patient cultures did not significantly differ from control cultures.

\section{Discussion}

FXYD2 (Na,K-ATPase $\gamma$-subunit) is a kidney-specific regulator of Na,K-ATPase. Dominant renal hypomagnesemia associated with hypocalciurea has been linked to a $121 \mathrm{G} \rightarrow$ A mutation in the FXYD2 gene, resulting in a G41R substitution in the protein itself. Since the relation between the mutation and hypomagnesemia is not understood yet, we isolated proximal tubular cells from the urine of a healthy control subject and a patient carrying the above mutation and converted these into immortalized cell lines. mRNA of both FXYD2a and FXYD2b was shown to be present and the $121 \mathrm{G}$ to A mutation, associated with hypomagnesemia, was detected in the patient cell line. At the protein level we show that both cell lines contained FXYD2 and the catalytic $\alpha$-subunit of Na,K-ATPase. We furthermore show that both proteins can be upregulated by culturing the cells under hypertonic conditions.

The induction of FXYD2 in our cell lines is in agreement with the literature (Capasso et al. 2001; Wetzel et al. 2004), as is the decline in FXYD2 protein over prolonged time periods when normal medium is used. The absence of any induction by $200 \mathrm{~mm}$ urea, which diffuses freely through the cells, indicates that these cell lines express FXYD2 particularly when cultured in an environment with
Fig. $4 \mathrm{Na}, \mathrm{K}$-ATPase activity of control and patient cell lines. Na,K-ATPase activity for both cell lines from both sucroseinduced and noninduced cultures in the presence of $3 \mathrm{~mm}$ ATP, $10 \mathrm{~mm} \mathrm{~K}^{+}$and $100 \mathrm{~mm}$ $\mathrm{Na}^{+}(\mathbf{a})$. When ATPase activity is corrected for $\alpha$-subunit expression (Fig. 3), all samples show similar activity (b).

Shown are means \pm SE of three enzyme preparations
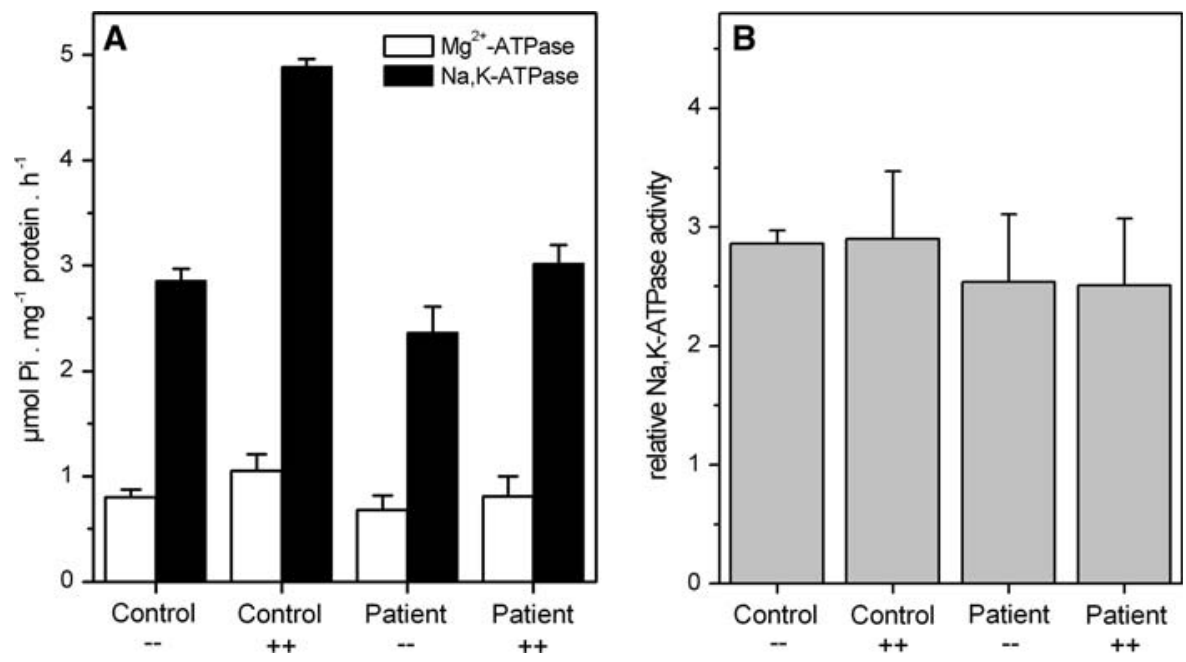


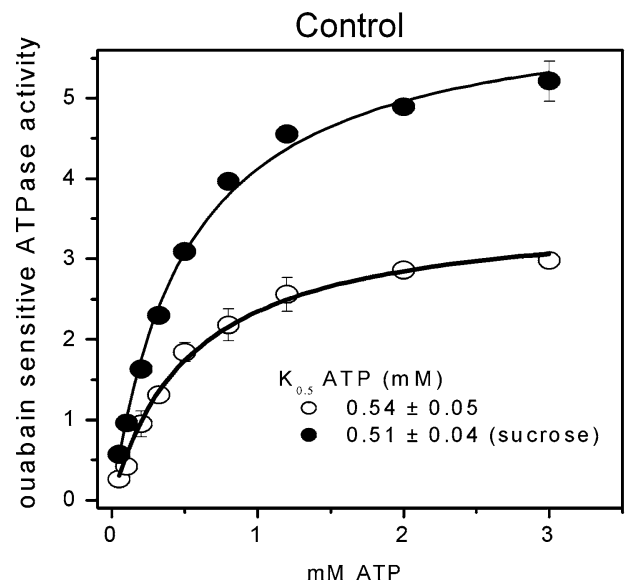

Fig. 5 Effects of ATP on Na,K-ATPase activity. ATPase activity was measured in membrane preparations as described in "Materials and Methods" in the presence of $0.1 \mathrm{~mm}$ EGTA, $0.2 \mathrm{~mm}$ EDTA, $0.8 \mathrm{~mm} \mathrm{MgCl}_{2}, 1.0 \mathrm{~mm}$ Tris- $\mathrm{N}_{3}, 100 \mathrm{~mm} \mathrm{NaCl}$ and $10 \mathrm{~mm} \mathrm{KCl}$, at $\mathrm{pH}$ 7.0. Ionic strength was kept constant with choline chloride. Samples

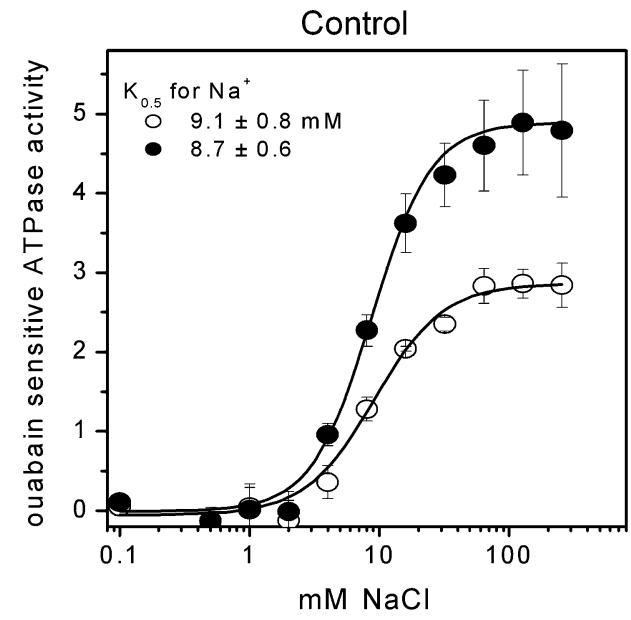

Fig. 6 Effects of $\mathrm{NaCl}$ on $\mathrm{Na}, \mathrm{K}-\mathrm{ATPase}$ activity. ATPase activity was measured in membrane preparations as described in "Materials and Methods" in the presence of $0.1 \mathrm{~mm}$ EGTA, $0.2 \mathrm{~mm}$ EDTA, $0.8 \mathrm{~mm} \mathrm{MgCl}_{2}, 1.0 \mathrm{~mm}$ Tris- $\mathrm{N}_{3}, 10 \mathrm{~mm} \mathrm{KCl}$ and $2.0 \mathrm{~mm} \mathrm{MgATP}$ at $\mathrm{pH}$ 7.0. Ionic strength was kept constant with choline chloride.

extracellular hyperosmolality. This indicates the existence of a regulatory system in which FXYD2 is upregulated to modulate the function of $\mathrm{Na}, \mathrm{K}$-ATPase so that it better suits the cellular environment. Moreover, upregulation of FXYD2 is $\mathrm{Na}^{+}$-independent and $\mathrm{Cl}^{-}$-dependent. This result confirms the data of Capasso et al. (2003), who showed that in IMCD3 cells chloride stimulates expression of FXYD2 and activates JNK in response to hypertonicity.

On the mRNA level we show the presence of FXYD2a and FXYD2b, as well as their mutated forms, in patient cells. Unfortunately, the antibody used in this study cannot distinguish between these two splice variants, nor can it distinguish between wild-type and G41R mutant FYXD2.

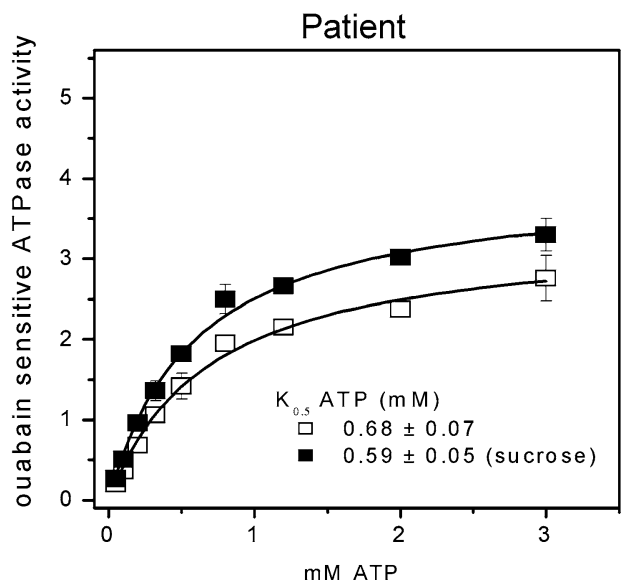

from noninduced cultures are represented by open symbols. Samples from cultures induced with an additional $200 \mathrm{mosmol} / \mathrm{kg} \mathrm{H}_{2} \mathrm{O}$ of sucrose are represented by closed symbols. Shown are means \pm SE of three enzyme preparations

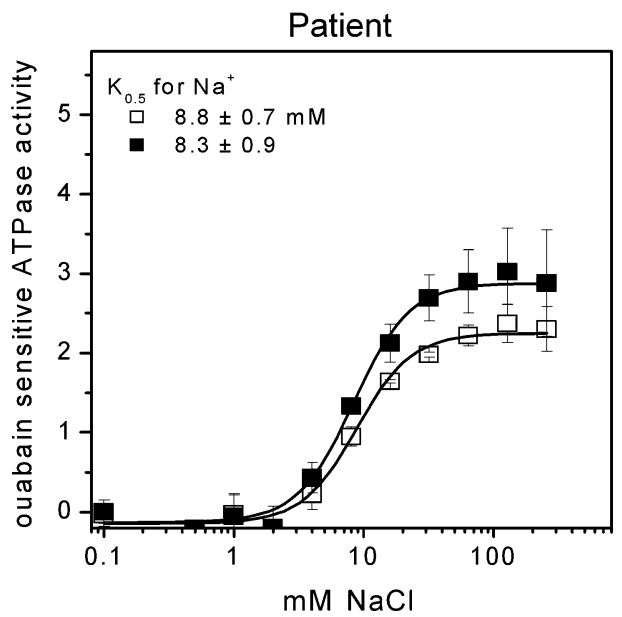

Samples from noninduced cultures are represented by open symbols. Samples from cultures induced with an extra $200 \mathrm{mosmol} / \mathrm{kg} \mathrm{H}_{2} \mathrm{O}$ of sucrose are represented by closed symbols. Shown are means \pm SE of three enzyme preparations

Earlier work using recombinant protein obtained from cRNA-injected Xenopus leavis oocytes revealed a distinct difference in molecular mass between wild-type and mutant protein on SDS-PAGE (Meij et al. 2003). However, in our isolated cells we could not detect this difference in molecular mass. A similar lack of difference in gel migration was found in HeLa cells transfected with either wild-type FXYD2b or G41R-mutated FXYD2b (Pu et al. 2002). We therefore cannot say with certainty that both wild-type and mutant FXYD2 are present in protein form. If the mutated FXYD2 is quickly degraded after upregulation, only the wild-type FXYD2 will be observed. In previous studies it was shown that the routing of FXYD2- 


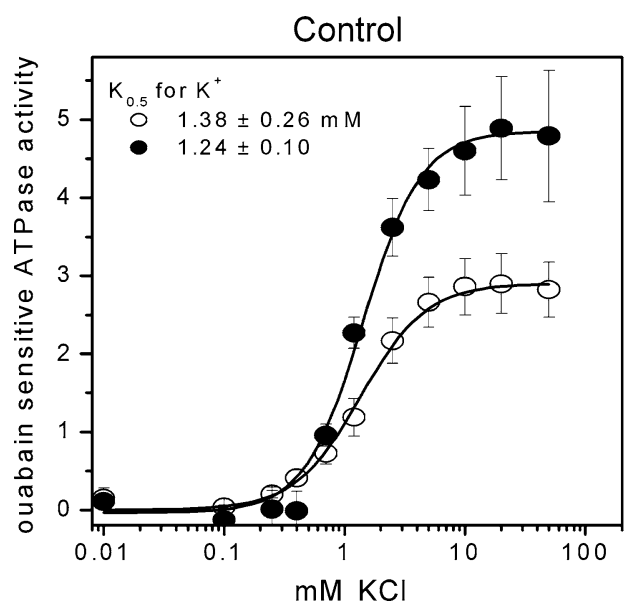

Fig. 7 Effects of $\mathrm{KCl}$ on $\mathrm{Na}, \mathrm{K}-\mathrm{ATPase}$ activity. ATPase activity was measured in membrane preparations as described in "Materials and Methods" in the presence of $0.1 \mathrm{~mm}$ EGTA, $0.2 \mathrm{~mm}$ EDTA, $0.8 \mathrm{~mm}$ $\mathrm{MgCl}_{2}, 1.0 \mathrm{~mm}$ Tris- $\mathrm{N}_{3}, 100 \mathrm{~mm} \mathrm{NaCl}$ and $2.0 \mathrm{~mm} \mathrm{MgATP}$, at $\mathrm{pH}$ 7.0. Ionic strength was kept constant with choline chloride. Samples

Table 1 Apparent Na,K-ATPase affinities for ATP, $\mathrm{Na}^{+}$and $\mathrm{K}^{+}$of membrane samples from noninduced control cultures, induced control cultures, noninduced patient cultures and induced patient cultures

\begin{tabular}{llll}
\hline & $\begin{array}{l}\text { ATP affinity } \\
(\mathrm{mM})\end{array}$ & $\begin{array}{l}\mathrm{Na}^{+} \text {affinity } \\
(\mathrm{mM})\end{array}$ & $\begin{array}{l}\mathrm{K}^{+} \text {affinity } \\
(\mathrm{mM})\end{array}$ \\
\hline Control -- & $0.54 \pm 0.05$ & $9.1 \pm 0.8$ & $1.38 \pm 0.26$ \\
Control ++ & $0.51 \pm 0.04$ & $8.7 \pm 0.6$ & $1.24 \pm 0.10$ \\
Patient -- & $0.68 \pm 0.07$ & $8.8 \pm 0.7$ & $1.79 \pm 0.18$ \\
Patient ++ & $0.59 \pm 0.05$ & $8.3 \pm 0.9$ & $1.61 \pm 0.11$ \\
\hline
\end{tabular}

Values are derived from Figs. 5, 6, and 7

G41R is impaired and that it can prevent the correct routing of wild-type FXYD2 (Meij et al. 2000; Cairo et al. 2008). Immunohistochemical scanning of patient cells might indicate if FXYD2 is indeed retarded. However, due to high intracellular background signals with the current antibody, we were unable to draw any conclusion about the localization of FXYD2 (data not shown).

$\mathrm{Na}, \mathrm{K}$-ATPase activity measurements on isolated membranes showed no significant changes in cation or ATP affinities between the two cell lines, irrespective of induction. The wild-type cell line showed a significant increase in total ATPase activity, but this can be explained by the increase in the total amount of Na,K-ATPase $\alpha$ subunit. When ATPase activity was corrected for the amount of $\alpha$-subunit detected on Western blot, all samples displayed the same activity, regardless of origin or induction state, indicating that an increase in $\mathrm{Na}, \mathrm{K}$-ATPase activity is due to upregulation of Na,K-ATPase. Whereas these findings are in agreement with an earlier study in which the $\alpha$-subunit and subsequent activity were increased in a primary culture of human proximal tubule cells

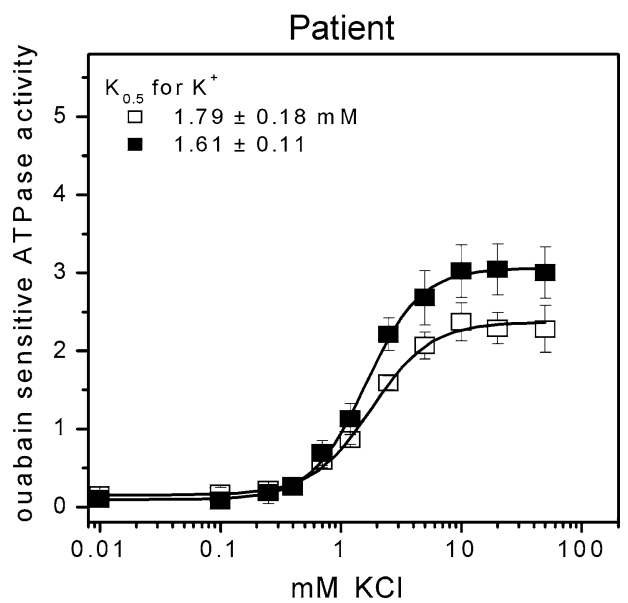

from noninduced cultures are represented by open symbols. Samples from cultures induced with an extra $200 \mathrm{mosmol} / \mathrm{kg} \mathrm{H}_{2} \mathrm{O}$ of sucrose are represented by closed symbols. Shown are means \pm SE of three enzyme preparations

exposed to hypertonicity (Yordy and Bowen 1993), they are at odds with studies performed by Wetzel et al. (2004). The latter authors show a reduction in the maximal activity of $\mathrm{Na}, \mathrm{K}-\mathrm{ATPase}$ after hyperosmotic induction of NRK-52E cells in the presence of $10 \%$ FCS. We revealed stimulation of Na,K-ATPase activity (also in the presence of $10 \%$ FCS), which correlated with the amount of expressed $\alpha$ subunit. Whether this discrepancy is due to differences in cell type or induction of FXYD2 splice variants is unclear.

The major difference we found between the patient and control cell lines was the lower amount of FXYD2 expressed per milligram of protein in the isolated membranes obtained from the patient cell line under the various conditions compared to the control cell line under similar conditions (Fig. 3). The mutated FXYD2 is retarded in the Golgi network (Meij et al. 2003) and probably broken down more rapidly than the wild-type FXYD2. In heterozygous cells, oligomers between wild-type and mutant FXYD2 may be unable to leave the Golgi network, leading to increased breakdown (Cairo et al. 2008). Recently, it was shown that FXYD2 and the Na,K-ATPase $\alpha$-subunit do not traffic together to the plasma membrane and, thus, assemble at the plasma membrane to form a complex (Pihakaski-Maunsbach et al. 2008). We therefore can conclude that the reduced Na,K-ATPase response to hypertonicity in patient cells is not due to interaction with the mutated FXYD2. It is likely that the absolute decrease of hyperosmolarity induced upregulation of FXYD2 and that the $\mathrm{Na}, \mathrm{K}$-ATPase $\alpha$-subunit in isolated patient cells also happens in vivo. Reduced overexpression of the FXYD2 subunit in response to hypertonic stress can affect cell survival or might lead to changes in intracellular ATP levels (Capasso et al. 2006). Eventually, this decrease of 
upregulation will have adverse effects on magnesium homeostasis by some hitherto unknown mechanism.

Although we discuss only two single cell lines here, we analyzed the first cell line to be created from cells isolated from the urine of a patient with the G41R mutation linked to dominant renal hypomagnesemia associated with hypocalciuria. We show that FXYD2 can be induced in these cells and that in hypertonically challenged patient cells the amount of $\mathrm{Na}, \mathrm{K}$-ATPase $\alpha$-subunit and FXYD2 is reduced. As such, these cell lines represent a valuable tool for research into the disorder. Isolating and producing cell lines from other patients is the next step for future experiments.

Acknowledgement This work was supported by the Netherlands Organization for Scientific Research (projects 908-02-126 and 86304-011).

Open Access This article is distributed under the terms of the Creative Commons Attribution Noncommercial License which permits any noncommercial use, distribution, and reproduction in any medium, provided the original author(s) and source are credited.

\section{References}

Arystarkhova E, Wetzel RK, Asinovski NK, Sweadner KJ (1999) The gamma subunit modulates $\mathrm{Na}+$ and $\mathrm{K}+$ affinity of the renal $\mathrm{Na}$, K-ATPase. J Biol Chem 274:33183-33185

Beguin P, Wang X, Firsov D, Puoti A, Claeys D, Horisberger JD, Geering K (1997) The gamma subunit is a specific component of the Na, K-ATPase and modulates its transport function. EMBO J $16: 4250-4260$

Beguin P, Crambert G, Guennoun S, Garty H, Horisberger JD, Geering K (2001) CHIF, a member of the FXYD protein family, is a regulator of $\mathrm{Na}$, K-ATPase distinct from the gamma-subunit. EMBO J 20:3993-4002

Beguin P, Crambert G, Monnet-Tschudi F, Uldry M, Horisberger JD, Garty H, Geering K (2002) FXYD7 is a brain-specific regulator of Na, K-ATPase alpha1-beta isozymes. EMBO J 21:3264-3273

Cairo ER, Friedrich T, Swarts HG, Knoers NV, Bindels RJ, Monnens LA, Willems PH, De Pont JJ, Koenderink JB (2008) Impaired routing of wild type FXYD2 after oligomerisation with FXYD2G41R might explain the dominant nature of renal hypomagnesemia. Biochim Biophys Acta 1778:398-404

Capasso JM, Rivard C, Berl T (2001) The expression of the gamma subunit of Na-K-ATPase is regulated by osmolality via Cterminal Jun kinase and phosphatidylinositol 3-kinase-dependent mechanisms. Proc Natl Acad Sci USA 98:13414-13419

Capasso JM, Rivard CJ, Enomoto LM, Berl T (2003) Chloride, not sodium, stimulates expression of the gamma subunit of $\mathrm{Na} / \mathrm{K}$ ATPase and activates JNK in response to hypertonicity in mouse IMCD3 cells. Proc Natl Acad Sci USA 100:6428-6433

Capasso JM, Rivard CJ, Berl T (2006) Silencing and overexpression of the gamma-subunit of Na-K-ATPase directly affect survival of IMCD3 cells in response to hypertonic stress. Am J Physiol 291:F1142-F1147

Crambert G, Fuzesi M, Garty H, Karlish S, Geering K (2002) Phospholemman (FXYD1) associates with Na, K-ATPase and regulates its transport properties. Proc Natl Acad Sci USA 99:11476-11481
Crambert G, Li C, Claeys D, Geering K (2005) FXYD3 (Mat-8), a new regulator of Na, K-ATPase. Mol Biol Cell 16:2363-2371

Delprat B, Schaer D, Roy S, Wang J, Puel JL, Geering K (2007) FXYD6 is a novel regulator of Na, K-ATPase expressed in the inner ear. J Biol Chem 282:7450-7456

Detrisac CJ, Sens MA, Garvin AJ, Spicer SS, Sens DA (1984) Tissue culture of human kidney epithelial cells of proximal tubule origin. Kidney Int 25:383-390

Koenderink JB, Geibel S, Grabsch E, De Pont JJ, Bamberg E, Friedrich $\mathrm{T}$ (2003) Electrophysiological analysis of the mutated Na, KATPase cation binding pocket. J Biol Chem 278:51213-51222

Laemmli UK (1970) Cleavage of structural proteins during the assembly of the head of bacteriophage T4. Nature 227:680-685

Laube GF, Haq MR, van't Hoff WG (2005) Exfoliated human proximal tubular cells: a model of cystinosis and Fanconi syndrome. Pediatr Nephrol 20:136-140

Li C, Crambert G, Thuillard D, Roy S, Schaer D, Geering K (2005) Role of the transmembrane domain of FXYD7 in structural and functional interactions with $\mathrm{Na}$, K-ATPase. J Biol Chem 280:42738-42743

Lubarski I, Pihakaski-Maunsbach K, Karlish SJ, Maunsbach AB, Garty $\mathrm{H}$ (2005) Interaction with the $\mathrm{Na}$, K-ATPase and tissue distribution of FXYD5 (related to ion channel). J Biol Chem 280:37717-37724

Meij IC, Koenderink JB, van Bokhoven H, Assink KF, Groenestege WT, De Pont JJ, Bindels RJ, Monnens LA, van den Heuvel LP, Knoers NV (2000) Dominant isolated renal magnesium loss is caused by misrouting of the $\mathrm{Na}+, \mathrm{K}+$-ATPase gamma-subunit. Nat Genet 26:265-266

Meij IC, Koenderink JB, De Jong JC, De Pont JJ, Monnens LA, van den Heuvel LP, Knoers NV (2003) Dominant isolated renal magnesium loss is caused by misrouting of the $\mathrm{Na}+, \mathrm{K}+-$ ATPase gamma-subunit. Ann N Y Acad Sci 986:437-443

Or E, Goldshleger ED, Tal DM, Karlish SJ (1996) Solubilization of a complex of tryptic fragments of $\mathrm{Na}$, K-ATPase containing occluded Rb ions and bound ouabain. Biochemistry 35:6853-6864

Peterson GL (1983) Determination of total protein. Methods Enzymol 91:95-119

Pihakaski-Maunsbach K, Nonaka S, Maunsbach AB (2008) Expression and trafficking of the gamma subunit of Na,K-ATPase in hypertonically challenged IMCD3 cells. Acta Histochem Cytochem 41:105-114

Pu HX, Scanzano R, Blostein R (2002) Distinct regulatory effects of the Na,K-ATPase gamma subunit. J Biol Chem 277:2027020276

Racusen LC, Wilson PD, Hartz PA, Fivush BA, Burrow CR (1995) Renal proximal tubular epithelium from patients with nephropathic cystinosis: immortalized cell lines as in vitro model systems. Kidney Int 48:536-543

Ryan MJ, Johnson G, Kirk J, Fuerstenberg SM, Zager RA, Torok-Storb B (1994) HK-2: an immortalized proximal tubule epithelial cell line from normal adult human kidney. Kidney Int 45:48-57

Therien AG, Karlish SJ, Blostein R (1999) Expression and functional role of the gamma subunit of the $\mathrm{Na}, \mathrm{K}$-ATPase in mammalian cells. J Biol Chem 274:12252-12256

Wetzel RK, Pascoa JL, Arystarkhova E (2004) Stress-induced expression of the gamma subunit (FXYD2) modulates Na,KATPase activity and cell growth. J Biol Chem 279:41750-41757

Wilmer MJ, de Graaf-Hess A, Blom HJ, Dijkman HB, Monnens LA, van den Heuvel LP, Levtchenko EN (2005) Elevated oxidized glutathione in cystinotic proximal tubular epithelial cells. Biochem Biophys Res Commun 337:610-614

Yordy MR, Bowen JW (1993) Na,K-ATPase expression and cell volume during hypertonic stress in human renal cells. Kidney Int 43:940-948 